Published by LPMP Imperium

Journal homepage: https:/ / ejournal.imperiuminstitute.org/ index.php/JMSAB

\section{Pengaruh kemudahan penggunaan, kepercayaan konsumen \& kreativitas iklan terhadap minat beli konsumen online-shop}

\author{
Khusnul Khotimah* \\ Fakultas Bisnis, Institut Teknologi dan Bisnis Kalbis, Jakarta, Indonesia
}

\section{Febriansyah}

Fakultas Bisnis, Institut Teknologi dan Bisnis Kalbis, Jakarta, Indonesia

\begin{abstract}
This study aims to determine the effect of ease of use, consumer trust and advertising creativity on consumer buying interest in online buying and selling sites, Bukalapak.com. This study uses a quantitative approach by conducting surveys and tests on 115 respondents. In the data analysis technique used is multiple linear regression analysis. The testing technique using the help of the SPSS 22 system. The results of hypothesis testing ( $t$ test) which shows that the variables of consumer trust and advertising creativity have a significant effect on the performance variable. But the ease of use variable has no significant effect on performance variables. The conclusion of this study is that consumer trust and advertising creativity are the most dominant variables for buying interest.
\end{abstract}

\begin{abstract}
Abstrak
Penelitian ini bertujuan untuk mengetahui pengaruh kemudahan penggunaan, kepercayaan konsumen dan kreativitas iklan terhadap minat beli konsumen di situs jual beli online Bukalapak.com. Penelitian ini menggunakan pendekatan kuantitatif dengan melakukan survey dan pengujian kepada 115 responden. Dalam teknik analisis data yang digunakan adalah analisis regresi linier berganda. Teknik pengujian dengan mengunakan bantuan sistem SPSS 22. Hasil uji hipotesis (uji t) yang menunjukkan bahwa variabel kepercayaan konsumen dan kreativitas iklan berpengaruh signifikan terhadap variabel kinerja. Namun variabel kemudahan penggunaan berpengaruh tidak signifikan terhadap variabel kinerja. Kesimpulan dari penelitian ini adalah kepercayaan konsumen dan kreativitas iklan merupakan variabel yang paling dominan atas minat beli.
\end{abstract}

*Email korespondensi: khusnulkh3107@gmail.com

Pedoman Sitasi: Khotimah, K., dan Febriansyah. (2018). Pengaruh kemudahan penggunaan, kepercayaan konsumen dan kreativitas iklan terhadap minat beli konsumen online-shop. Jurnal Manajemen Strategi dan Aplikasi Bisnis, 1(1), 19 - 26
JMSAB

Paper type

Research paper

Keywords: Ease of use, consumer trust, creativity of advertising, purchase intention

Received: 18 November 2018

Accepted: 1 December 2018

Online: 31 December

2018

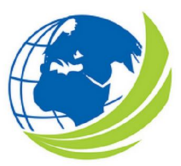
Jurnal Manajemen
Strategi dan Aplikasi
Bisnis, Vol 1, No.1,
Desember 2018,
pp.19-26
eISSN 2655-237X 


\section{Pendahuluan}

Di era globalisasi seperti sekarang ini, teknologi sangat erat kaitannya dengan internet. Menurut Strauss, El-Ansary, dan Frost (2003: 8) internet adalah seluruh jaringan yang saling terhubung satu sama lain. Beberapa komputer-komputer dalam jaringan ini menyimpan file, seperti halaman web, yang dapat diakses oleh seluruh jaringan komputer. Pendapat ini sejalan dengan Laudon dan Traver (2012: 60) yang mengartikan internet adalah jaringan-jaringan komputer di seluruh dunia yang dibangun berdasarkan standar umum.

Pengguna internet Indonesia hingga Juni 2016 mencapai 88 juta jiwa dari dari total populasi 258 juta jiwa, dengan penestrasi terhadap populasi sekitar 34 persen. Total pengguna internet di Asia mencapai 1,7 miliar dari total populasi 4,1 miliar jiwa. Sekitar 721 juta pengguna internet berasal dari Cina atau 40 persen, sementara dari Indonesia hanya mencapai 4,9 persen dari total pengguna internet di Asia. Besarnya populasi penduduk Cina dan India membuat pengguna internet di kedua negara tersebut cukup tinggi.

Salah satu perkembangan internet yang sangat dimaksimalkan potensinya bisa kita lihat dari segi bisnis, di mana perkembangan sistem jual beli online tersebut pun sudah sangat pesat terjadi di Indonesia secara khusus. Bahkan sudah banyak perusahaan-perusahaan yang berskala nasional maupun swasta yang menerapkan teknologi informasi tersebut (Norhermaya, 2016: 1). Jual beli online adalah aktifitas jual beli berupa transaksi penawaran barang oleh penjual dan permintaan barang oleh pembeli secara online dengan memanfaatkan teknologi internet (Irwan, 2014: 8).

Berdasarkan data Asosiasi Penyelenggara Jasa Internet Indonesia (APJII), perilaku pengguna internet Indonesia yang mengetahui dan menjadikan internet sebagai tempat menawarkan atau mencari barang dan jasa sebesar $98,6 \%$ atau sebesar 130,8 juta dan $63,5 \%$ atau sebesar 84,2 juta yang pernah bertransaksi online.

Di Indonesia sendiri ada banyak situs E-commerce yang menawarkan produk baik barang maupun jasa, salah satunya adalah Bukalapak.com. Bukalapak.com dimiliki dan dikelola oleh PT. Bukalapak. Bukalapak.com berfokus pada tipe E-commerce C2C (Costumer to Customer). Sama halnya seperti situs jual beli online lainnya yang berbasis C2C, Bukalapak.com menyediakan sarana penjualan dari konsumen ke konsumen dimanapun dan siapapun dapat membuka toko online untuk melayani calon pembeli dari seluruh Indonesia. Pengguna perorangan ataupun perusahaan dapat membeli dan menjual produk, baik baru maupun bekas, seperti sepeda, perlengkapan bayi, gadget, aksesoris gadget, komputer, perlengkapan rumah tangga, busana, elektronik dan lain-lain.

Sepanjang tahun 2017, Lazada dan Tokopedia berada di posisi pertama dan kedua sebagai Ecommerce paling banyak dicari. Ini terjadi karena banyak factor yaitu Lazada yang di tahun ini mendapat peningkatan saham dari Alibaba dari 51\% ke 83\%, beserta beberapa event promosi yang cukup rajin yakni promo ulang tahun mereka, single's day (11.11) dan kampanye online shopping revolution (12.12). Di sisi lain, Tokopedia juga memiliki momentum besar tahun ini yakni aliran dana segar dari Alibaba sebesar USD 1,1 miliar. Di awal tahun 2017, selisih jumlah search interest antara Shopee dan Bukalapak.com cukup besar. Namun di penghujung tahun ini, Shopee berhasil mengungguli Bukalapak.com.

Minat beli konsumen, merupakan salah satu bagian dari komponen dalam sikap konsumen mengkonsumsi suatu produk. Minat yang muncul dalam melakukan pembelian menciptakan suatu motivasi berada dalam pikiran seseorang dan menjadi suatu kegiatan yang sangat kuat yang pada akhirnya ketika seorang konsumen harus memenuhi kebutuhannya akan mengaktualisasikan apa yang ada didalam pikiran tersebut. Sebagaimana yang diungkapkan Setiawati (2015: 3) jika seseorang mempunyai motivasi yang tinggi terhadap obyek tertentu, maka dia akan terdorong untuk berperilaku menguasai produk tersebut. Sebaliknya, jika motivasinya rendah, maka dia akan mencoba untuk menghindari obyek yang bersangkutan.

Menurut Alwafi dan Magnadi (2016) kepercayaan pembeli terhadap situs jual beli online terletak pada popularitas situs tersebut, semakin popular situs tersebut pembeli akan merasa lebih 
yakin untuk berbelanja disana. Karena situs jual beli online bersifat umum, konsumen terkadang tidak yakin terhadap penjual dan hasil dari transaksinya. Oleh karena itu, situs jual beli online harus bertindak untuk menghilangkan ketidakyakinan konsumen, tindakan ini berupa pemberian keamanan dan membangun kepercayaan melalui interaksi kepada konsumen.

Kreativitas iklan juga menumbuhkan minat beli konsumen terhadap produk yang ditawarkan (Adi, 2016: 4). Dalam penyampaian pesan, isi atau makna yang terkandung didalam iklan harus bisa membuat konsumen berfikir, menafsirkan dan memahami apa yang dimaksud inti dari informasi yang disajikan. Jika sebuah produk sudah dimengerti oleh konsumen, secara otomatis isi atau makna dari iklan yang disampaikan menimbulkan sebuah respon didalam pikiran konsumen sehingga menimbulkan minat untuk melakukan pembelian. Pesan yang dibuat oleh iklan E-commerce agar melekat di pikiran para konsumen yang melihatnya. Sehingga membuat konsumen semakin penasaran ingin berbelanja di situs jual beli online Bukalapak.com. Dengan adanya iklan yang kreatif, minat beli konsumen semakin besar sebelum benar-benar memutuskan untuk membeli produk atau jasa.

Dari uraian diatas, maka tujuan dari penelitian adalah untuk mengetahui dan menganalisis kemudahan penggunaan, kepercayaan konsumen, kreativitas iklan berpengaruh terhadap minat beli konsumen secara bersamaan dan parsial di situs jual beli online Bukalapak.com.

\section{KAJIAN PUSTAKA}

Kemudahan Penggunaan

Kemudahan penggunaan didefinisikan sebagai suatu tingkat atau keadaan dimana seseorang yakin bahwa dengan menggunakan sistem tertentu tidak diperlukan usaha apapun (free of effort) atau teknologi tersebut dapat dengan mudah dipahami oleh pengguna (Davis dalam Andryanto, 2016: 26).

\section{Kepercayaan Konsumen}

Kepercayaan konsumen adalah keyakinan seorang konsumen bahwa orang lain memiliki integritas dan dapat dipercaya, serta orang yang dipercayainya akan memenuhi segala kewajibannya dalam melakukan transaksi sesuai dengan yang diharapkan (Nurrahmanto, 2017: 32).

Kreativitas Iklan

Kreativitas iklan adalah how to say (bagaimana mengatakan) sebuah pesan periklanan atau cara yang dilakukan untuk mengkomunikasikan pesan iklan what to say (apa yang harus dikatakan) kepada audiens (Adi, 2016: 23).

\section{Minat Beli}

Minat beli diperoleh melalui proses belajar dan proses pemikiran yang membentuk persepsi. Minat beli menciptakan suatu motivasi terhadap pikiran konsumen, yang pada akhirnya ketika konsumen harus memenuhi kebutuhannya maka akan mengaktualisasikan apa yang ada di dalam pikirannya. Minat beli berhubungan dengan perasaan dan emosi, bila seseorang senang dan puas dalam membeli suatu produk maka hal itu akan memperkuat minat belinya. Menurut Kinnear dan Taylor dalam Andryanto (2016: 21), minat beli merupakan tahap kecenderungan konsumen untuk bertindak sebelum keputusan membeli benar-benar dilaksanakan. 


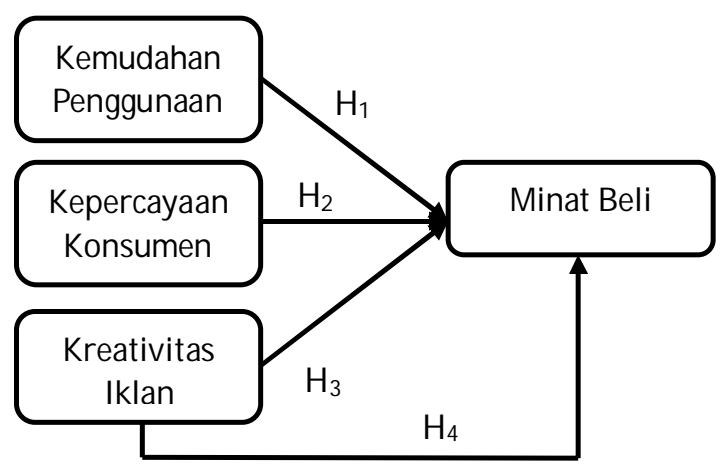

\section{Gambar 1. Model Kerangka Penelitian}

\section{Hipotesis Penelitian}

Berdasarkan tujuan dan model dari penelitian ini, maka hipotesis yang diajukan adalah:

$\mathrm{H}_{1}$ : Kemudahan penggunaan berpengaruh terhadap minat beli

$\mathrm{H}_{2}$ : Kepercayaan konsumen berpengaruh terhadap minat beli

$\mathrm{H}_{3}$ : Kreativitas Iklan berpengaruh terhadap minat beli

$\mathrm{H}_{4}$ : Secara bersama-sama kemudahan penggunaan, kepercayaan konsumen, dan kreativitas iklan berpengaruh terhadap minat iklan

\section{METODE PENELITIAN}

Desain Penelitian

Penelitian ini menggunakan metode kuantitatif, yaitu data penelitian berupa angka-angka dan analisis menggunakan statistik (Sugiyono, 2012:23). Penelitian kuantitatif menekankan pada pengujian teori-teori melalui pengukuran variabel-variabel penelitian dengan angka dan melakukan analisis data dengan prosedur statistik (Indriantoro, 2012:12). Variabel yang diteliti dalam penelitian ini yaitu kemudahan penggunaan, kepercayaan konsumen dan kreativitas iklan sebagai variabel independen (variabel bebas) dan minat beli sebagai variabel dependen (variabel terikat).

Populasi dan Sampel

Populasi adalah gabungan seluruh elemen yang memiliki serangkaian karakteristik serupa yang mencakup semesta untuk kepentingan riset pemasaran (Malhotra, 2009). Populasi yang digunakan pada penelitian ini adalah konsumen Bukalapak.com di wilayah Jakarta yang mengetahui, pernah melihat iklan Bukalapak.com di televisi dan melakukan pembelian di situs jual beli online tersebut. Dalam menentukan jumlah sampel, penelitian ini menggunakan teori menurut Malhotra (2010), dimana dijelaskan jika populasi tidak diketahui, maka sampel dapat diambil dengan menghitung jumlah pertanyaan (n) dikali lima. Keseluruhan pertanyaan dalam penelitian ini berjumlah 23 pertanyaan sehingga jika dikalikan dengan lima maka sampel yang diperoleh adalah sebanyak 115 sampel.

Operasionalisasi variabel

Minat Beli

Menurut Ferdinand (2006), minat beli dapat diidentifikasikan melalui dimensi-dimensi sebagai berikut yaitu minat transaksional, minat referensial, minat preferensial dan minat eksploratif.

Kemudahan Penggunaan

Venkatesh dan Davis dalam Andryanto (2016:27) membagi dimensi persepsi kemudahan penggunaan menjadi Interaksi individu dengan sistem jelas dan mudah dimengerti, tidak dibutuhkan 
Jurnal Manajemen Strategi dan Aplikasi Bisnis, 1(1), 1-8

Khotimah \& Febriansyah, pengaruh kemudahan penggunaan, kepercayaan konsumen...

banyak usaha untuk berinteraksi dengan sistem tersebut, sistem mudah digunakan dan mudah mengoperasikan sistem sesuai dengan apa yang ingin individu kerjakan.

Kepercayaan Konsumen

Menurut Mayer et al dalam Andika (2016:13-14) persepsi kepercayaan dalam transaksi online didasarkan pada tiga komponen, yaitu Ability (kemampuan), integrity (integritas) dan benevolence (perbuatan baik).

Kreativitas Iklan

Pengukuran kreativitas iklan menggunakan indikator yang diadopsi dari Handoko (2006: 30) yang meliputi original, tidak terduga dan mudah dipahami.

Teknik Analisis

Teknik analisis untuk model penelitian ini adalah dengan pendekatan statistik melalui analisis regresi linier berganda dengan pengolah software statistik yaitu SPSS versi 22. Menurut Sunyoto (2011: 145) analisis regresi linier berganda dipakai untuk mengetahui besarnya pengaruh variabel bebas (Kemudahan Penggunaan, Kepercayaan Konsumen, Kreativitas Iklan) terhadap variabel terikat (Minat Beli) dengan rumus regresi sebagai berikut, yaitu:

\section{$\mathbf{Y}=\mathbf{b o}+\mathbf{b}_{1} \mathbf{X}_{1}+\mathbf{b}_{2} \mathbf{X}_{2}+\mathbf{b}_{3} \mathbf{X}_{3}$}

Keterangan:

Y : Minat Beli

bo : Konstanta

$\mathrm{b}_{1}, \mathrm{~b}_{2}, \mathrm{~b}_{3} \quad$ : Koefisien Regresi

$\mathrm{X}_{1} \quad$ : Kemudahan Penggunaan

$\mathrm{X}_{2} \quad$ : Kepercayaan Konsumen

$\mathrm{X}_{3} \quad$ : Kreativitas Iklan

\section{HASIL DAN PEMBAHASAN}

Analisis Regresi Berganda

Setelah melakukan uji asumsi klasik (uji normalitas, uji multikolinearitas, dan uji heterokedastisitas) sehingga data tersebut layak dan memenuhi syarat untuk melakukan pengujian hipotesis pada model penelitian ini. Tujuan dari analisis regresi berganda yaitu untuk mengetahui pengaruh variabel bebas yaitu Kemudahan Penggunaan/ KP $\left(\mathrm{X}_{1}\right)$, Kepercayaan Konsumen/ KK $\left(\mathrm{X}_{2}\right)$, Kreativitas Iklan/ KI $\left(\mathrm{X}_{3}\right)$ terhadap variabel terikat yaitu Minat Beli (Y).

Tabel 1. Output Analisis Regresi Linier Berganda

\begin{tabular}{lccccc}
\hline \multirow{2}{*}{ Model } & \multicolumn{2}{c}{$\begin{array}{c}\text { Undstandardized } \\
\text { Coeffecients }\end{array}$} & $\begin{array}{c}\text { Standardized } \\
\text { Coefficients }\end{array}$ & & \\
\cline { 2 - 4 } & $\mathbf{B}$ & Std. Error & Beta & t & Sig. \\
\hline Konstant & -0.435 & 1.278 & & -0.34 & 0.735 \\
KP & 0.144 & 0.074 & 0.177 & 1.939 & 0.055 \\
KK & 0.297 & 0.067 & 0.421 & 4.397 & 0.000 \\
KI & 0.186 & 0.066 & 0.261 & 2.803 & 0.006 \\
\hline
\end{tabular}

Sumber: SPSS Versi 22 
Berdasarkan hasil Tabel 1 diatas, maka model penelitian yang diajukan dalam persamaan regresi linier berganda adalah sebagai berikut:

\section{Minat Beli $=\mathbf{- 0 , 4 3 5}+$ 0,144 Kemudahan Penggunaan + 0,297 Kepercayaan Konsumen + 0,186 Kreativitas Iklan + e}

Model persamaan regresi liner berganda diatas, dapat diuraikan bahwa nilai dari Konstanta sebesar 0,435, menyatakan bahwa minat beli sebesar -0,435, apabila nilai dari masing-masing variabel kemudahan penggunaan, kepercayaan konsumen dan kreativitas iklan dianggap konstan atau bernilai nol. Koefesien regresi untuk variabel kemudahan pelanggan (X1) sebesar 0,144 artinya jika variabel independen lain nilainya tetap dan kemudahan penggunaan mengalami kenaikan 1 poin, maka variabel minat beli (Y) akan mengalami kenaikan sebesar Rp. 0.144.

Nilai dari koefisien regresi variabel kepercayaan konsumen (X2) sebesar 0,297 artinya jika variabel independen lain nilainya tetap dan kepercayaan konsumen mengalami kenaikan 1 poin, maka variabel minat beli (Y) akan mengalami kenaikan sebesar Rp. 0.297. Dan koefisien regresi variabel kreativitas iklan (X3) sebesar 0,186 artinya jika variabel independen lain nilainya tetap dan kreativitas iklan mengalami kenaikan 1 poin, maka variabel minat beli (Y) akan mengalami kenaikan sebesar Rp. 0.186 .

Uji Hipotesis

Uji Signifikan Parsial (Uji-T)

Dalam uji hipotesis parsial (uji-t) digunakan untuk mengetahui ada tidaknya hubungan atau pengaruh yang berarti (signifikan) antara variabel independen (kemudahan penggunaan, kepercayaan konsumen dan kreativitas iklan) secara parsial terhadap variabel dependen (minat beli). Disajikan pada tabel 2, hasil Uji-T dari model regresi dalam penelitian ini, sebagai berikut:

Tabel 2. Output Uji-T

\begin{tabular}{lcc}
\hline \multicolumn{1}{r}{ Model } & t & Sig. \\
\hline Konstant & -0.34 & 0.735 \\
KP & 1.939 & 0.055 \\
KK & 4.397 & 0.000 \\
KI & 2.803 & 0.006 \\
\hline
\end{tabular}

Sumber: SPSS Versi 22

Berdasarkan hasil Uji-T yang disajikan pada Tabel 2, dapat ditarik kesimpulan variabel kemudahan penggunaan (KP) dengan nilai t-hitung adalah 1.939 yang menunjukan bahwa t-hitung $\leq \mathrm{t}$-kritis $=$ $1,939 \leq 1,981$. Hasil ini mengindikasikan bahwa variabel kemudahan penggunaan (X1) tidak berpengaruh terhadap minat beli $(\mathrm{Y})$, sehingga menolak $\mathrm{H}_{1}$. Nilai variabel kepercayaan konsumen (X2) dengan t-hitung sebesar 4,397 > 1,981, maka mengindikasikan bahwa variabel kepercayaan konsumen (X2) berpengaruh terhadap variabel minat beli (Y). Dengan demikian menerima $\mathrm{H}_{2}$. Dan variabel kreativitas iklan (X3) yang membuktikkan nilai t-hitung adalah 2,803 >1,981, menyatakan bahwa variabel kreativitas iklan (X3) berpengaruh terhadap variabel minat beli (Y), sehingga menerima $\mathrm{H}_{3}$. 
Jurnal Manajemen Strategi dan Aplikasi Bisnis, 1(1), 1-8

Khotimah \& Febriansyah, pengaruh kemudahan penggunaan, kepercayaan konsumen...

Uji Simultan (Uji-F)

Uji-F digunakan untuk mengetahui tingkat signifikansi pengaruh dari variabel kemudahan penggunaan, kepercayan konsumen, dan kreativitas iklan secara bersama-sama (Simultan) terhadap minat beli. Berikut hasil uji-F yang disajikan pada Tabel 3 yaitu sebagai berikut :

\section{Tabel 3. Output Uji-F}

\begin{tabular}{lrc}
\multicolumn{4}{c}{ ANOVAa } \\
\hline \multicolumn{1}{c}{ Model } & F & \multicolumn{1}{c}{ Sig. } \\
\hline $1 \quad$ Regression & 57.183 & $.000 \mathrm{~b}$ \\
\hline a. Dependen Variabel: MB & \\
b. Predictors: (Constant), KI, KP, KK & \\
Sumber: SPSS Versi 22 &
\end{tabular}

Dari tabel 3 diatas bahwa hasil uji-f menunjukan nilai f-hitung $\geq \mathrm{f}$ kritis $=57,183>2,686$ dan tingkat signifikasi $0,000 \geq 0,05$. Hal ini menjelaskan bahwa Ho ditolak, yang mengartikan bahwa variabel kemudahan penggunaan (X1), kepercayaan konsumen (X2) dan kreativitas iklan (X3) sebagai variabel independen dengan hasil secara bersamaan memiliki pengaruh terhadap variabel terikat minat beli (Y).

\section{KESIMPULAN}

Kesimpulan

Berdasarkan dari hasil analisis dan pembahasan maka penelitian ini dapat diperoleh kesimpulan sebagai berikut bahwa kemudahan penggunaan (X1) positif tidak berpengaruh dan tidak signifikan terhadap minat beli (Y), sedangkan kepercayaan konsumen (X2) dan kreativitas iklan (X3) berpengaruh positif dan signifikan terhadap variabel minat beli (Y). Temuan lainnya bahwa secara bersama-sama antara kemudahan penggunaan (X1), kepercayaan konsumen (X2) dan kreativitas iklan (X3) berpengaruh terhadap variabel minat beli (Y).

Keterbasan dan Saran

Penelitian ini memiliki keterbatasan dari sampel penelitian, yaitu hanya mengambil dari satu jenis bisnis on-line yaitu Bukalapak.com, sehingga hasil penelitian tidak bisa digeneralisasi untuk model penelitian ini. Keterbatasan lainnya yaitu tidak ada populasi dalam penelitian yang dijelaskan dengan spesifik. Untuk penelitian mendatang, objek penelitian ditambahkan dan populasi penelitian lebih diperjelas untuk pengambilan sampel. Riset selanjutnya disarankan dapat menggunakan berbagai variasi variabel penelitian terkait dengan faktor determinan dalam minat beli, sehingga temuan penelitian lebih dapat digeneralisasi dan lebih variatif kajiannya.

\section{REFERENSI}

Adi, P. E. (2016). Pengaruh Kreativitas Iklan, Unsur Humor, dan Kualitas Pesan Iklan Terhadap Efektivitas Iklan Televisi Aqua "Versi Ada Aqua. Skripsi Sarjana Ekonomi Universitas Negeri Yogyakarta. Yogyakarta.

Alwafi \& Magnadi. (2016). Pengaruh Persepsi Keamanan, Kemudahan Bertransaksi, Kepercayaan Terhadap Toko dan Pengalaman Berbelanja Terhadap Minat Beli Secara Online Pada Situs Jual Beli Tokopedia.com. Diponegoro Journal Of Management, Vol. 5, No. 2, Hal 2.

Andika, B. (2016). Analisis Website Quality, Trust dan Loyalty Pelanggan Lazada (Studi pada Masyarakat Kota Yogyakarta). Skripsi Sarjana Ekonomi Universitas Negeri Yogyakarta. Yogyakarta. 
Andryanto, R. (2016). Pengaruh Kepercayaan, Persepsi Manfaat dan Persepsi Kemudahan Penggunaan Terhadap Minat Beli di Toko Online (Studi Empiris yang Dilakukan Pada OLX.co.id di Yogyakarta). Skripsi Sarjana Ekonomi Universitas Negeri Yogyakarta. Yogyakarta.

Ferdinand. (2006). Pengembangan Minat Beli Merek Ekstensi. Semarang: Badan Penerbit Universitas Diponegoro.

Indriantoro, N. \& Supomo, B. (2012). Metodologi Penelitian Bisnis Untuk Akuntansi Dan manajemen. Yogyakarta: BPFE Yogyakarta.

Laudon, C. K., dan Traver, C. G. (2012). E-commerce 2012. Eighth Edition. USA: Pearson Prentice Hall.

Malhotra, N. K. (2009). Riset Pemasaran Pendekatan Terapan. Edisi Keempat. Jakarta: Indeks.

Malhotra, N. K. (2010). Riset Pemasaran (Marketing Research). Edisi Keempat Jilid Satu. Jakarta: PT. Indeks.

Norhermaya, A. Y (2016). Pengaruh Kepuasan Pelanggan Terhadap Kepercayaan dan Loyalitas Pelanggan Untuk Meningkatkan Minat Beli Ulang (Studi Kasus Online Store Lazada.co.id). Skripsi Sarjana Fakultas Ekonomi dan Bisnis Universitas Diponegoro. Semarang.

Nurrahmanto, A. P. (2015). Pengaruh Kemudahan Penggunaan, Kenikmatan Berbelanja, Pengalaman Berbelanja dan Kepercayaan Konsumen Terhadap Minat Beli Konsumen di Situs Jual Beli Online Bukalapak.com. Skripsi Sarjana Ekonomika dan Bisnis Universitas Diponergoro. Semarang.

Setiawati, M. (2015). Pengaruh Media Sosial Terhadap Minat Beli Konsumen Studi Kasus Mahasiswa Manajemen Universitas Pasir Pengaraian. Skripsi Sarjana Ekonomi Universitas Pasir Pengaraian. Riau.

Sugiyono. (2012). Metode Penelitian Kombinasi (Mix Metode). Bandung: Alfabeta.

Sunyoto, D. (2011). Metodologi Penelitian Ekonomi. Yogyakarta: CAPS.

\section{PROFIL PENULIS}

Khusnul Khotimah adalah dosen prodi manajemen, Fakultas Bisnis Institut Teknologi dan Bisnis Kalbis. Email korespondesi adalah khusnulkh3107@gmail.com

Febryansyah adalah dosen prodi manajemen, Fakultas Bisnis Institut Teknologi dan Bisnis Kalbis. Email korespondesi adalah febriansyah@kalbis.ac.id 